\title{
Return and Risk Comparative Analysis in the Formation of Optimal Share Portfolio with Random Model, Markowitz Model, and Single Index Model
}

\author{
Abdul Muslim ${ }^{1 *}$ \\ Institut Ilmu Sosial dan Manajemen STIAMI, Jakarta, Indonesia \\ Email : abdulmuslim78@gmail.com \\ Corresponding
}

ARTICLE INFO

Article history

Received 2020-05-22

Revised 2020-09-05

Accepted 2020-09-19

Keywords

Liquidity, profitability, stock returns

\begin{abstract}
This research was conducted to determine the composition of the stock portfolio formed by the Random model, the Markowitz model, and the Single Index model and which portfolio composition was optimal from the results of calculations using the Random model, the Markowitz model, and the Single Index model. The method used is a quantitative analysis using stock price data in the LQ45 Index group listed on the Indonesia Stock Exchange (IDX). In the first random process the results of calculating the expected return value for each share and obtained portfolio candidates can produce a total expected return of 0.2726 or $27.26 \%$. The Markowitz method produces 14 shares that have a positive value, which means it enters into portfolio-forming shares, while the Single Index Model obtains diversified investments in the form of a portfolio of 6 shares
\end{abstract}

\section{INTRODUCTION}

Indonesia's economic growth is relatively low when compared to several developed countries in the ASEAN region. This is shown by the economic growth lagging behind by the three main ASEAN countries, namely Malaysia, the Philippines, and Vietnam and if compared to the 2 ASEAN countries it will be superior to Singapore and Thailand. This relatively small growth is inversely proportional to Indonesia's population. In the ASEAN region, Indonesia is the country with the largest population, which is more than 265 million people.

Increased investment is something that requires special attention for economic growth. This is important because the activities to increase an investment can be used as an instrument to normalize the economy, open employment opportunities, and reduce poverty. A high investment value can provide a strong stimulus to the country's economy and vice versa if low investment can hinder development and the implication is that the number of unemployed will increase.

To increase economic growth to a high direction, it is necessary to have a positive growth in investment value for the survival of business actors because the most effective source of capital formation is domestic savings, however domestic capital formation in Indonesia is still low, so that the role of investment in the market is still needed. capital. Investment for the general public is equated with giving investment or equity participation is one of the economic activities that affects the level of aggregate spending. Expenditures in the economic sector include household spending, investments made by companies, and financing for exports and imports.

One of the instruments or places for financial investment is the capital market which plays an important role in the world economy. In addition, the capital market is also a place to bring together parties who have excess funds or landers and parties who need funds or borrowers (Hartono 2016). The existence of a capital market can help landers and borrowers carry out business activities efficiently and effectively.

Investing in stock instruments can be an alternative if investors want a maximum rate of return. The investment value in the form of stock instruments provides an opportunity with a 
growth rate of return that requires a lot of time and risk which is also equivalent to this. To get the opportunity to get a high level of profit, investors (investors) must be brave enough to bear high risks as well. Profits and risks play an important role in making investment decisions (Mary and Rathika, 2016). So by doing a portfolio analysis, an investor must be rational in choosing and determining strategies to minimize risk and increase the return value. Investment as an option to increase the value and wealth owned.

Fahmi and Hadi (2009) explain that investment activities are generally known to have two options for making real investment (real investment) which generally involves tangible assets, such as land, machinery or factories and financial investment generally involves contract assets. written, such as common stock and bonds. The difference between investing in real investment and financial investment is the level of liquidity of the two investments. Investments in real investment are relatively difficult to cash in because they will face long-term commitments between investors (investors) and the company. Meanwhile, investment (investment) in financial investment is easy to withdraw it can be cashed immediately without being bound by time by way of trading.

Investment as part of financial business activities and is a form of investment, either directly or indirectly, either in the short term or in the long term, with the aim of obtaining the expected added value (profit) or other forms of added value with benefits as a result of the investment itself. Thus, the investment has a return that is desired by investors (investors).

Risk is something that requires attention in carrying out investment or investment activities because risk can be in the form of the possibility of not achieving the expected results or profits. Attention not to risk, return must also be considered because from return a return is obtained from an investment of funds and capital investment invested in an investment. In general, investors make investment (investment) with the main objective to be able to obtain results in the form of returns on their money. Stock return is the income (income) obtained by shareholders as a result of their investment in the company (Jones, 2002).

In general, the risk exists in every investment choice, however the high or low risk depends on the type of investment. Investments in stocks are considered to have a higher level of risk compared to deposits and savings, because the expected return probability in a certain period cannot be realized is very large. In order for investment to provide optimal results, investors or potential investors must be able to assess the risks and returns contained in the planned investment alternatives.

One form of risk called systematic risk. Systematic risk is also said to be market risk (market risk), this is because market risk fluctuates by factors that affect all companies that are running or operating. These influencing factors include economic conditions and tax policy. Systematic risk is a risk that arises from market and economic turmoil globally so that it has a strong influence. Reoritically, the capital market emphasizes that the relationship between market risk and the rate of return is a unidirectional and linear relationship. This means that the greater the risk that must be covered, the greater the return on the investment.

As it is known that the characteristic of securities is that it is easy to manipulate investment portfolios, so that investors can easily diversify their investments into various investment opportunities. This engineering is carried out by considering the combination of investment types in the hope of obtaining optimal returns on the level of return and by minimizing risk. Before investing, investors would like to know how the performance or performance of the stock instruments to be invested.

To understand the stock performance, it is best to take an approach that potential investors can seek, namely the return and risk approach. With the hope of this approach, investors will get an overview of the return and risk characteristics of the invested shares. By not knowing the size of the risk for the shares invested, investors will find it difficult to determine the return.

A portfolio with optimal results can be obtained from a variety of securities from an efficient portfolio. Portfolios with optimal results are obtained by selecting a certain expected rate of return and then estimating the expected return.

Previous research to find stocks that deserve to be included in the optimal portfolio. This study used the LQ 45 Index for the period August 2015-January 2016 as a population, because stocks listed on the LQ 45 Index are the most liquid stocks. The sample was selected using the census method. The analysis technique used was portfolio analysis using the Single Index Model. 
The results of this study showed that out of 45 stocks there were 9 stocks that were eligible for the optimal portfolio (Reza et al., 2017). Research using the Single Index Model was also conducted. on LQ 45 Index stocks with the results of 4 stocks that are candidates for a portfolio of 14 stocks (Abdilah \& Rahayu, 2013).

Another study has been conducted by comparing the Single Index Model and the Random Model on stocks in the Compass Index 100. The results of the study by examining the differences between the two models show that the optimal portfolio using the Single Index Model can provide higher returns than the Random portfolio (Putu et al. ., 2016), In line with this study, research by comparing the two models of determining the stock portfolio uses a random model. The sample in this study is 25 stocks that are members of SRI-KEHATI. The results show that determining the stock portfolio using a single index model can provide optimal returns compared to determining the stock portfolio using a random model (Sari \& Triyani, 2018)

Another study tested 15 company stocks that are members of the LQ 45 Index with the Markowitz Model. The Markowitz model is considered easier to apply because the optimal portfolio is assessed only based on the lowest point on the surface of the efficient portfolio. (Maf'ula z, Handayani RS, 2014). Research comparing the Single Index Model and the Markowitz Model conducted on 300 JII stocks provides evidence that the optimal portfolio formation of the single index model is more efficient than the Markowitz model. The empirical results of this study have implications for investors and the development of portfolio formation theory related to investment in JII / Jakarta Islamic Index stocks. (Yuliani \& Achsani, 2017)

Based on previous research, not many have tested the optimal portfolio by comparing the three models: Single Index Model, Random Model and Markowitz Model in one test. This study aims to analyze the composition of the stock portfolio formed by the Random model, the Markowitz model, and the Single Index model, as well as the optimal composition of the stock portfolio from the calculation using the Random model, the Markowitz model, and the Single Index model.

\section{METHOD}

The type of data used in this study is secondary data in the form of stock price data in the LQ45 Index group which is listed on the Indonesia Stock Exchange (BEI). The data used in this study were obtained from historical data sources for closing stock prices in the LQ45 Index group listed on the IDX during the period January 2015 to December 2019 obtained from the Indonesia Stock Exchange (IDX).

\section{Data analysis technique}

The data analysis method used is quantitative analysis with the data analysis steps as follows.

1. Calculate stock returns and stock risk

2. Calculating the error risk

The variance of the residual error is a variable that shows the amount of unsystematic risk that is unique to the company, which can be calculated using a formula (Jogiyanto, 2010).

$$
\sigma m^{2}=\frac{\sum_{i-1}^{n}\left(R m-E(R m)^{2}\right.}{n-1}
$$

Where:

$$
\begin{array}{ll}
\sigma m^{2} & =\text { Market return variance } \\
R m & =\text { Market returns } \\
E(R m) & =\text { Market expected returns } \\
n & =\text { Number of observation periods }
\end{array}
$$

3. Calculating the portfolio for each model as follows:

$$
\text { a. Random Model }
$$


Determination of the optimal portfolio using a random model is done by selecting stocks randomly without considering the characteristics of the investor. With a sample of a number of stocks in the LQ45 Index group by choosing a portfolio randomly.

b. Markowitz model

1) To calculate stock returns using the formula

$$
R_{i t}=\left(P_{i t}-P_{i t-1}\right)+D_{1} / P_{i t-1}
$$

Information:

$\mathrm{R}_{\mathrm{it}} \quad=\quad$ Return at the expected time

$\mathrm{P}_{\mathrm{t}-1}=\quad$ Share price at the beginning of the period

$\mathrm{P}_{\mathrm{t}}=\quad$ Share price at the end of the period

$\mathrm{D}_{1} \quad=\quad$ Dividends distributed

2) Calculating the Expected Return of each share with the formula:

$E\left(R_{i}\right)=\frac{\sum_{i=1}^{n} R_{i}}{N}$

Information:

$E\left(R_{\mathrm{i}}\right) \quad: \quad$ Individual stock expected returns

$\mathrm{R}_{\mathrm{i}} \quad: \quad$ Individual stock returns

$\mathrm{N} \quad$ : $\quad$ Number of periods

3) Calculating the Risk (variance and standard deviation) of investment of each share.

This risk measure is intended to find out how likely it is that the value obtained deviates from the value we expect. We can find the calculation with the formula:

$\sigma^{2}=\frac{\sum_{i=1}^{n}\left[\left(R_{i j}-E\left(R_{i}\right)\right]^{2}\right.}{N}$

Or

$\sigma_{i}=\sqrt{\sigma^{2}}$

Information:

$\sigma^{2}=\quad$ Variance

$\sigma_{\bar{i}}=$ Standard deviation

$R_{i j}:=\quad$ The level of profit that has been obtained

$E\left(R_{i}\right)=\quad$ The expected rate of return on investment $\mathrm{i}$

$\mathrm{N}=$ The number of events that may occur

4) Calculating the correlation coefficient of stock prices between companies.

The size of the correlation coefficient will affect portfolio risk. The formula used is:

$\rho=\frac{n \sum X Y-\sum X \sum Y}{\sqrt{\left\{\left[n \sum X^{2}-\left(X^{2}\right)\right]\left[n \sum Y^{2}-\left(Y^{2}\right]\right)\right\}}}$

Information:

$\rho=$ Correlation coefficient

$\mathrm{n}=$ Number of observations

$\mathrm{X}=$ the expected rate of return on stock $\mathrm{X}$

$\mathrm{Y}=$ the expected rate of return on the stock $\mathrm{Y}$

5) Determining the proportion of funds from portfolio candidate stocks is done using the Solver application program that is in Microsoft Excel. This application will provide the best proportion of funds in order to produce the maximum return. 
6) Calculating the Expected Return (the level of expected profit) from the portfolio. The level of profit expected from the portfolio can be calculated using the formula:

$E\left(R_{p}\right)=\sum_{i=1}^{N} X_{i} E\left(R_{i}\right)$

Information:

$E\left(R_{\mathrm{p}}\right) \quad$ : The expected rate of return on the portfolio

$X_{i} \quad$ : Proportion of funds invested in stocks i

$\mathrm{E}\left(\mathrm{R}_{\mathrm{i}}\right) \quad$ : The expected rate of return on investment $\mathrm{i}$

$\mathrm{N} \quad$ : Number of periods

7) Calculating the Risk (variance and standard deviation) of the portfolio. The variance and standard deviation of the portfolio can be calculated from the following equation:

$\sigma_{p}^{2}=X_{1}^{2} \sigma_{1}^{2}+X_{2}^{2} \sigma_{2}^{2}+2\left(X_{1} X_{2} \rho_{12} \sigma_{1} \sigma_{2}\right)$

Information:

$\sigma_{p}^{2}=\quad$ Portfolio variance

$\sigma_{1}^{2}=$ Stock variant 1

$\sigma_{2}^{2}=$ Stock variance 2

$\rho_{12}=$ The correlation coefficient between the levels of stock returns 1 and 2

$X_{1} X_{2}=\quad$ The proportion of funds invested in stocks 1 and 2

c. Single Index Model

Single Securities Return according to Hartono (2003) is divided into two parts, namely:

1. Return realization (realized return), namely the return that has occurred.

In a single index model of security returns can be formulated into an equation (Hartono,

2003):

$\mathrm{Ri}=\alpha \mathrm{i}+\beta \mathrm{i} . \mathrm{Rm}$ ei.

Where:

Ri: stock return i

Ai: the expected value of stock returns that is independent of market returns

$\mathrm{Bi}$ : beta which is the coefficient measuring the change in $\mathrm{Ri}$ as a result of the change in

$\mathrm{Rm}$

Rm: return market

Ei: residual error which is a random variable with an expected value equal to zero or $\mathrm{E}$ $(\mathrm{Ri})=0$.

The single index model divides security returns into two main components, namely:

a) Return components that are unique and independent of market returns; denoted by $\alpha$ i.

b) Return components related to market returns; denoted by $\beta \mathrm{i}$. The unique return component ( $\alpha \mathrm{i})$ is only related to micro events that only affect certain companies. Meanwhile, the return component related to market return ( $\beta \mathrm{i}$ ) concerns macro events that affect all firms.

2. Expected return, namely the return that is expected to be obtained by investors in the future. The single index model can also be expressed in terms of expected returns. The expected return of a single security from this model can be stated as follows (Hartono, 2003):

$\mathrm{E}(\mathrm{Ri})=\alpha \mathrm{i}+\beta \mathrm{i} . \mathrm{E}(\mathrm{Rm})$

Where:

$\mathrm{E}$ (Ri): expected stock return i

ai: the expected value of stock returns that is independent of market returns

$\beta \mathrm{i}$ : beta which is a coefficient measuring the change in $\mathrm{Ri}$ as a result of changes in $\mathrm{Rm}$

$\mathrm{E}(\mathrm{Rm})$ : expected return market 
The measurements used to form the optimal portfolio with the Single Index Model in this study are as follows:

1) Actual return and expected stock return

Actual stock returns can be found using the following equation:

$R_{i}=\frac{p_{t}-p_{t-1}}{p_{t-1}}$

Information:

$\mathrm{Ri}=$ Return of stock realization period $\mathrm{t}$

$\mathrm{Pt}=$ share price period $\mathrm{t}$

Pt-1 = The share price of the previous period

The expected return can be calculated using the following formula (Halim, 2015: 44):

$\mathrm{E}(\mathrm{Ri})=\frac{2_{\mathrm{i}}^{\mathrm{n}} \mathrm{o}\left(R_{\mathrm{i}}\right)}{N}$

Information:

$\mathrm{E}(\mathrm{Ri})=$ expected return of stock $\mathrm{i}$

$\mathrm{Ri}=$ actual return of stock $\mathrm{i}$

$\mathrm{N}=$ number of events that occurred

2) Market return and expected market return

Market return is the market rate of return as reflected in the Composite Stock Price Index (IHSG). Market return can be calculated with the formula (Utamayasa and Wiagustini, 2016: 3915):

$R_{m}=\frac{I H S G_{\mathrm{t}}-I H S G_{\mathrm{t}-1}}{I H S G_{\mathrm{t}-1}}$

Information:

$\mathrm{Rm}=$ market return

IHSGt $=$ composite stock price index period $\mathrm{t}$

IHSGt-1 = composite stock price index for period $\mathrm{t}-1$

The expected market return can be calculated using the following formula:

$\mathrm{E}\left(\mathrm{R}_{m}\right)=\frac{\sum_{i-0}^{n}\left(R_{m}\right)}{N}$

Information:

$\mathrm{E}(\mathrm{Rm})=$ expected market return

$\mathrm{Rm}=$ market return

$\mathrm{N}=$ number of events that occurred

3) The stock standard deviation and the market standard deviation

The standard deviation is the square root of the variance. Standard deviation can be used to measure the risk between expected return and actual return. The standard deviation of a stock can be found using the formula (Halim, 2015):

$\sigma_{\mathrm{i}}=\sqrt{\frac{\sum_{i=0}^{n}\left\{R_{\mathrm{i}}-\mathrm{E}\left(\mathrm{R}_{\mathrm{i}}\right)\right\}^{2}}{N}}$

Information:

$\sigma \mathrm{i}=$ standard deviation of shares $\mathrm{i}$

$\mathrm{Ri}=$ actual return from investment in stocks $\mathrm{i}$

$\mathrm{E}(\mathrm{Ri})=$ expected return of stock investment $\mathrm{i}$

$\mathrm{n}=$ number of events that may occur

The market standard deviation can be found using the formula:

$\sigma_{m}=\sqrt{\frac{\sum_{i-0}^{n}\left\{R_{m}-\mathrm{E}\left(\mathrm{R}_{m}\right)\right\}^{2}}{N}}$ 
Information:

$\sigma \mathrm{m}=$ market standard deviation

$\mathrm{Rm}=$ market return

$\mathrm{E}(\mathrm{Rm})=$ expected market return

$\mathrm{N}=$ number of events that may occur

4) Stock beta

Beta $(\beta i)$ is a coefficient that measures the sensitivity of changes in stock returns to market returns and shows systematic risk. Beta can be searched using the help of the SPSS program or by using the following formula (Husnan, 2005)

$\beta_{i}=\frac{\dot{\sigma_{i, m}}}{\sigma_{m}^{2}}$

Information:

$\beta \mathrm{i}=$ stock beta $\mathrm{i}$

$\sigma \mathrm{i}, \mathrm{m}=$ covariance of return between stock $\mathrm{i}$ and market return

$\sigma \mathrm{m} 2=$ variance of market returns

5) Alpha stock

Alpha ( $\alpha \mathrm{i})$ is an independent variable and is not influenced by market returns. Alpha can be searched using the help of the SPSS program or with the following formula (Husnan, 2005: 108):

$\alpha_{i}=E\left(R_{i}\right)-\beta i . E\left(R_{m}\right)$

Information:

$\alpha \mathrm{i}=$ stock alpha $\mathrm{i}$

$\beta \mathrm{i}=$ stock beta $\mathrm{i}$

$\mathrm{E}(\mathrm{Rm})=$ average return from the market index

$\mathrm{E}(\mathrm{Ri})=$ average return from stock $\mathrm{i}$

6) The variance of the residual error

The variance of the residual error shows the unique unsystematic risk that occurs within the company, which can be calculated by the equation (Nalini, 2014: 87):

$\sigma_{\text {ei }}^{2}=\sigma_{i}^{2}-\beta_{i}^{2} \cdot \sigma_{m}^{2}$

Information:

$=$ the variance of the residual error

$=$ stock variance $\mathrm{i}$

$=$ stock beta

$=$ variance of stock returns

7) Risk free return on assets

In this study, risk-free asset returns are represented by daily SBI interest rates during the 2015-2019 period. Based on Yulandari (2014: 68), daily Rf can be found by averaging the SBI interest rate by 360 days.

8) Excess Return to Beta (ERB)

Excess Return to Beta (ERB) is the difference between the expected return and riskfree asset return which is then divided by beta using the formula (Fakhruddin and Hadianto, 2001: 193):

$\mathrm{ERB}_{i}=\frac{E\left(R_{i}\right)-R_{f}}{\beta_{i}}$

Information:

$=$ excess return to stock beta $\mathrm{i}$

$=$ expected return of stocks $\mathrm{i}$ 
$=$ risk free return on assets

$\beta \mathrm{i}=$ stock beta $\mathrm{i}$

9) Cut off point $(\mathrm{C} *)$

Cut Off Point $(\mathrm{C} *)$ is a limiting point used to determine whether a stock can be included in the portfolio or not. Cut Off Point $(\mathrm{C} *)$ is the largest value of the limiting point $(\mathrm{Ci})$ values of the stock candidate portfolio. Shares that are included in the portfolio are stocks that have ERB $\mathrm{C} *$. The value of $\mathrm{Ci}$ can be calculated by first calculating the value of $\mathrm{Ai}$ and $\mathrm{Bi}$ for each of the ith securities as follows (Fakhruddin and Hadianto, 2001: 194):

$A_{i}=\frac{\left\lfloor E\left(R_{i}\right)-R_{f}\right\rfloor \beta_{i}}{\sigma_{e i}^{2}}$

$\beta_{i}=\frac{\beta_{i}^{2}}{\sigma_{p i}^{2}}$

Where:

$\sigma_{e i}{ }^{2}=$ the variance of the residual error

$\mathrm{Ci}$ is searched by formula

$C_{i}=\frac{d_{m}^{2} \sum_{j=1}^{t} A_{i}}{1+d_{m}^{2} \sum_{j=1}^{t} \beta_{i}}$

Where:

$d_{m}^{2}=$ market return variance

$\mathrm{Ci}$ is the value of $\mathrm{C}$ for the $\mathrm{i}$-th share calculated from the accumulated values of $\mathrm{A} 1$ to $\mathrm{Ai}$ and the values of $\mathrm{B} 1$ to $\mathrm{Bi}$. For example, $\mathrm{C} 3$ shows the value of $\mathrm{C}$ for the $3 \mathrm{rd}$ stock calculated from the accumulation of A1, A2, and A3 as well as B1, B2, and B3.

10) Proportion of shares $i$

The proportion of shares $\mathrm{i}(\mathrm{Wi})$ is the proportion of funds of each share in the portfolio which can be calculated using the formula (Utamayasa and Wiagustini, 2016: 3919): $W_{i}=\frac{z_{i}}{\sum_{j=1}^{k} z_{j}}=$

The $\mathrm{Zi}$ value can be found with the following equation:

$Z_{i}=\frac{\beta_{i}}{\sigma_{p i}^{2}}\left(E R B_{i}-C *\right)=$

Information:

$\mathrm{Wi}=$ share proportion $\mathrm{i}$

$\mathrm{k}=$ the number of shares in the optimal portfolio

$\beta_{i}=$ stock beta

$\sigma_{e i}^{2}=\quad$ the variance of a security's residual error

$E R B_{i}=\quad$ excess return to beta stock i

$\mathrm{C}^{*}=$ cut-off-point value

11) Calculate the expected return of the portfolio

The portfolio's expected return is the weighted average of the individual returns of each portfolio-forming stock, which can be calculated using the formula (Husnan, 2005:

107).

$E\left(R_{p}\right)=\alpha_{p}+\beta_{p} E\left(R_{m}\right)$

where

$E\left(R_{p}\right) \quad=$ expected return portfolio

$\alpha_{p} \quad=$ alpha portfolio

$\beta_{p}=$ beta portfolio

$E\left(R_{m}\right) \quad=$ expected market return 
The alpha portfolio is the weighted average of the alpha of each stock which can be searched by the formula (Husnan, 2005):

$\alpha_{p}=\sum_{t=1}^{n}\left(W_{i}+\alpha_{i}\right)$

where

$\alpha_{p}=$ alpha portfolio

$W_{i}=$ proportion or weight of the security $\mathrm{i}$

$\alpha_{i}=$ alpha securities i

The portfolio beta is the weighted average of the beta of each security which can be calculated using the formula (Husnan, 2005):

$\beta_{p}=\sum_{t=1}^{n}\left(W_{i}+\beta_{i}\right)$

Information:

$\beta_{p}=$ beta portfolio

$W_{i}=$ proporsi atau bobot sekuritas i

$\beta_{i}=$ beta securities i

Portfolio risk is a weighted average of all single risks that can be calculated using the formula (Husnan, 2005: 107)

$\sigma_{p}^{2}=\beta_{p}^{2} \cdot \sigma_{m}^{2}+\sum_{i=1}^{n} W_{i}^{2} \sigma_{e i}^{2}$

Information:

$\sigma_{p}^{2}=$ portfolio variance

$\beta_{p}{ }^{2}=$ market-related risks

$W_{i}^{2} \sigma_{e i}^{2} \quad=$ weighted average of each firm's unique risks

2. Determining the Optimal Portfolio

\section{RESULTS AND DISCUSSION}

The population used as the object in this study are stocks that are included in the LQ 45 Index category during the 2015-2019 period. The index consists of 45 stocks with high liquidity and the largest capitalization. The composition of shares included in the LQ 45 index is always evaluated every six months so that the composition of these shares can vary each semester. The shares that do not meet the requirements will be issued and the new shares that meet the requirements will be added. Shares that exit LQ 45 can still re-enter if they meet the requirements. The technique used in determining the sample is purposive sampling, where the research sample is determined based on certain considerations. The criteria used for consideration include the following:

1. Shares listed on the LQ 45 Index during the 2015-2019 period.

2. Shares that have always been included in the LQ 45 category during the period August 2015-2019 respectively.

Based on the selection results, there are 21 stocks that meet the requirements to be the research sample. The list of stocks used as research samples can be seen in the following table:

List of LQ 45 Company Stock Samples for the Period 2015-2019

\begin{tabular}{|c|l|l|}
\hline No. & Code & \multicolumn{1}{c|}{ Stock Name } \\
\hline 1 & ADRO & Adaro Energy Tbk \\
\hline 2 & ASII & Astra International Tbk \\
\hline 3 & BBCA & Bank Central Asia Tbk \\
\hline 4 & BBNI & Bank Negara Indonesia (Persero) Tbk \\
\hline 5 & BBRI & Bank Rakyat Indonesia (Persero) \\
\hline 6 & BMRI & Bank Mandiri (Persero) Tbk \\
\hline
\end{tabular}




\begin{tabular}{|c|l|l|}
\hline No. & Code & \multicolumn{1}{|c|}{ Stock Name } \\
\hline 7 & GGRM & Gudang Garam Tbk \\
\hline 8 & ICBP & Indofood CPB Sukses Makmur Tbk \\
\hline 9 & INDF & Indofood Sukses Makmur Tbk \\
\hline 10 & INTP & Indocement Tunggal Prakasa Tbk \\
\hline 11 & JSMR & Jasa Marga (Persero) Tbk \\
\hline 12 & KLBF & Kalbe Farma Tbk \\
\hline 13 & PGAS & Perusahaan Gas Negara (Persero) Tbk \\
\hline 14 & PTBA & $\begin{array}{l}\text { Tambang Batubara Bukit Asam } \\
\text { (Persro) Tbk }\end{array}$ \\
\hline 15 & PWON & Pakuwon Jati Tbk. \\
\hline 16 & SMGR & Semen Indonesia (Persero) Tbk \\
\hline 17 & TLKM & $\begin{array}{l}\text { Telekomunikasi Indonesia (Persero) } \\
\text { Tbk }\end{array}$ \\
\hline 18 & UNTR & United Tractors Tbk \\
\hline 19 & UNVR & Unilever Indonesia Tbk \\
\hline 20 & WIKA & Wijaya Karya Tbk. \\
\hline 21 & WSKT & Waskita Karya Tbk. \\
\hline
\end{tabular}

Source: Random Sampling

The share price data of the companies that were the research sample from the period July 2015 to December 2019 are as follows:

Research Sample Stock Price Data for the Period of December 2015-2019

\begin{tabular}{|l|c|c|c|c|c|}
\hline $\begin{array}{l}\text { Stock } \\
\text { Code }\end{array}$ & 2015 & 2016 & 2017 & 2018 & 2019 \\
\hline ADRO & 515 & 1,695 & 1,860 & 1,215 & 1,555 \\
\hline ASII & 6,000 & 8,275 & 8,300 & 8,225 & 6,925 \\
\hline BBCA & 13,300 & 15,500 & 21,900 & 26,000 & 33,425 \\
\hline BBNI & 4,780 & 5,525 & 9,900 & 8,800 & 7,850 \\
\hline BBRI & 11,425 & 11,675 & 3,640 & 3,660 & 4,400 \\
\hline BMRI & 9,250 & 11,575 & 8,000 & 7,375 & 7,675 \\
\hline GGRM & 55,000 & 63,900 & 83,800 & 83,625 & 53,000 \\
\hline ICBP & 13,475 & 8,575 & 8,900 & 10,450 & 11,150 \\
\hline INDF & 5,175 & 7,925 & 7,625 & 7,450 & 7,925 \\
\hline INTP & 22,235 & 15,400 & 21,950 & 18,450 & 19,025 \\
\hline JSMR & 5,225 & 4,329 & 6,400 & 4,200 & 5,175 \\
\hline KLBF & 1,320 & 1,515 & 1,690 & 1,520 & 1,620 \\
\hline PGAS & 2,745 & 2,700 & 1,750 & 2,120 & 2,170 \\
\hline PTBA & 4,525 & 12,500 & 2,460 & 4,300 & 2,650 \\
\hline PWON & 416 & 565 & 685 & 620 & 570 \\
\hline SMGR & 11,400 & 9,175 & 9,900 & 11,500 & 12,000 \\
\hline TLKM & 3,105 & 3,980 & 4,440 & 3,750 & 3,970 \\
\hline UNTR & 16,950 & 21,250 & 35,400 & 27,350 & 21,575 \\
\hline UNVR & 37,000 & 38,800 & 55,900 & 45,400 & 42,000 \\
\hline WIKA & 2,640 & 2,360 & 1,550 & 1,655 & 1,990 \\
\hline WSKT & 1,670 & 2,550 & 2,210 & 1,680 & 1,485 \\
\hline
\end{tabular}

Based on the data above, the optimal portfolio calculation is carried out using the Random Method, the Markowitz Model, and the Single Index Model.

\section{Random Model}


The optimal portfolio calculation using a random model is done by choosing stocks randomly without paying attention to the characteristics of the investor, because the investor chooses at will. With a sample of 45 stocks will choose a portfolio randomly for four trials. The random selection step is carried out, which is to give the serial number of stocks from 1 to 21 , which is done by taking a sample of 10 stocks each. This was done four times by calculating the optimal return value for each experiment.

In the first random process, the results of the calculation of the expected return value for each stock are obtained and the candidate portfolio can produce a total expected return of 0.4270 or $42.70 \%$. In the second random process, the results of the calculation of the expected return value for each stock are obtained and the candidate portfolio can produce a total expected return of 0.2364 or $23.64 \%$. Furthermore, the third random process results in the calculation of the expected return value for each stock and the optimal portfolio candidate is obtained which can produce a total expected return of 0.488 or $48.84 \%$. Finally, the fourth random process results in the calculation of the value of the total expected return for each stock and the optimal candidate portfolio can produce a total expected return of 0.1408 or $14.08 \%$.

The random model uses four trials where the selected result is the third random process that produces the largest total expected return portfolio. The optimal portfolio candidates from the random model, namely ADRO, BBNI, BMRI, GGRM, ICBP, JSMR, PTBA, SMGR, TLKM, and WIKA have an expected return of 0.4884 or $48.84 \%$.

The results of measuring portfolio performance are: Sharpe Index, Treynor Index, and Jensen Index. This comparison aims to determine which portfolio calculations are more optimal than other portfolios.

1. Return E (Rp): $0.4884 \diamond 48.84 \%$

2. Standard Deviation $\sigma: 0.2057$

3. Beta $\beta: 1.0683$

4. Stock return Rf: 0.0102

5.Rm market return: 0.0288

6. Shape Ratio SR: 0.1882

7. Trenor Ratio TR: 0.0361

8. Jensen Ratio JR: 0.0187

The return variance is a risk that can be reduced by investment diversification, where the more shares that are included in the portfolio, the less systematic risk will be. The return variance figure shows the unique risk of each company owned by other companies.

\section{Markowitz Model}

To form a reliable portfolio, calculations can be made using the Microsoft Excel program. First, by looking for the return from the market, stock returns, and also stock risk. Market return, stock return, and stock risk are calculated using the average formula.

Based on the results of the calculation, the expected return and risk (variance and standard deviation) of each share are calculated as follows:

Results of the Expected Return and Variance and Standard Deviation of Each Share

\begin{tabular}{|l|c|c|c|}
\hline Stock Code & $E\left(R_{i}\right)$ & $\sigma^{2}$ & $\sigma_{\tilde{i}}$ \\
\hline ADRO & 0.0852 & 0.0670 & 0.2589 \\
\hline ASII & 0.0111 & 0.0143 & 0.1197 \\
\hline BBCA & 0.1323 & 0.0027 & 0.0516 \\
\hline BBNI & 0.0876 & 0.0429 & 0.2072 \\
\hline BBRI & -0.0095 & 0.0835 & 0.2890 \\
\hline BMRI & -0.0009 & 0.0315 & 0.1775 \\
\hline GGRM & 0.0321 & 0.0263 & 0.1622 \\
\hline ICBP & 0.0342 & 0.0255 & 0.1597 \\
\hline INDF & 0.0405 & 0.0163 & 0.1276 \\
\hline
\end{tabular}




\begin{tabular}{|l|c|c|c|}
\hline Stock Code & $E\left(R_{i}\right)$ & $\sigma^{2}$ & $\sigma_{\hat{i}}$ \\
\hline INTP & 0.0206 & 0.0543 & 0.2330 \\
\hline JSMR & 0.0096 & 0.0580 & 0.2409 \\
\hline KLBF & 0.0081 & 0.0154 & 0.1239 \\
\hline PGAS & -0.0775 & 0.0330 & 0.1817 \\
\hline PTBA & -0.0229 & 0.1413 & 0.3759 \\
\hline PWON & 0.0618 & 0.0420 & 0.2049 \\
\hline SMGR & -0.0007 & 0.0582 & 0.2413 \\
\hline TLKM & 0.0837 & 0.0389 & 0.1973 \\
\hline UNTR & 0.0396 & 0.0565 & 0.2377 \\
\hline UNVR & 0.0671 & 0.0352 & 0.1876 \\
\hline WIKA & 0.0002 & 0.0552 & 0.2350 \\
\hline WSKT & 0.1425 & 0.1687 & 0.4108 \\
\hline
\end{tabular}

The results of calculating the Expected Return in forming a Seham portfolio can be seen in the following table:

Candidate Portfolio Forming Shares

\begin{tabular}{|c|c|c|c|c|c|}
\hline No. & $\begin{array}{l}\text { Stock } \\
\text { Code }\end{array}$ & $\mathrm{E}(\mathrm{Ri})$ & $\mathrm{E}(\mathrm{Rm})$ & $\begin{array}{l}\text { E(Rm)- } \\
\text { E(Rm) }\end{array}$ & $\begin{array}{l}\text { Portfolio } \\
\text { Former }\end{array}$ \\
\hline 1 & WSKT & 0.1425 & 0.0242 & 0.1184 & Candidate \\
\hline 2 & $\mathrm{BBCA}$ & 0.1323 & 0.0242 & 0.1081 & Candidate \\
\hline 3 & BBNI & 0.0876 & 0.0242 & 0.0634 & date \\
\hline 4 & ADRO & 0.0852 & 0.0242 & 0.0611 & Candidate \\
\hline 5 & TLKM & 0.0837 & 0.0242 & 0.0595 & Candidate \\
\hline 6 & UNVR & 0.0671 & 0.0242 & 0.0429 & Candidate \\
\hline 7 & PWON & 0.0618 & 0.0242 & 0.0376 & Candidate \\
\hline 8 & INDF & 0.0405 & 0.0242 & 0.0163 & Candidate \\
\hline 9 & UNTR & 0.0396 & 0.0242 & 0.0154 & Candidate \\
\hline 10 & ICBP & 0.0342 & 0.0242 & 0.0100 & Candidate \\
\hline 11 & GGRM & 0.0321 & 0.0242 & 0.0080 & Candidate \\
\hline 12 & INTP & 0.0206 & 0.0242 & $\begin{array}{c}- \\
0.0036 \\
\end{array}$ & $\begin{array}{c}\text { Not } \\
\text { Candidate }\end{array}$ \\
\hline 13 & ASII & 0.0111 & 0.0242 & 0.0130 & $\begin{array}{l}\text { Not } \\
\text { Candidate }\end{array}$ \\
\hline 14 & JSMR & 0.0096 & 0.0242 & $\begin{array}{c}- \\
0.0145 \\
\end{array}$ & $\begin{array}{l}\text { Not } \\
\text { Candidate }\end{array}$ \\
\hline 15 & KLBF & 0.0081 & 0.0242 & $\begin{array}{c}- \\
0.0161 \\
\end{array}$ & $\begin{array}{l}\text { Not } \\
\text { Candidate }\end{array}$ \\
\hline 16 & WIKA & 0.0002 & 0.0242 & $\begin{array}{c}- \\
0.0240\end{array}$ & $\begin{array}{l}\text { Not } \\
\text { Candidate }\end{array}$ \\
\hline 17 & SMGR & $\begin{array}{c}- \\
0.0007\end{array}$ & 0.0242 & $\begin{array}{c}- \\
0.0249\end{array}$ & $\begin{array}{l}\text { Not } \\
\text { Candidate }\end{array}$ \\
\hline 18 & BMRI & $\begin{array}{c}- \\
0.0009\end{array}$ & 0.0242 & $\begin{array}{c}- \\
0.0250\end{array}$ & $\begin{array}{l}\text { Not } \\
\text { Candidate }\end{array}$ \\
\hline 19 & BBRI & $\begin{array}{c}- \\
0.0095\end{array}$ & 0.0242 & $\begin{array}{c}- \\
0.0337\end{array}$ & $\begin{array}{l}\text { Not } \\
\text { Candidate }\end{array}$ \\
\hline 20 & PTBA & $\begin{array}{c}- \\
0.0229 \\
\end{array}$ & 0.0242 & $\begin{array}{c}- \\
0.0471\end{array}$ & $\begin{array}{l}\text { Not } \\
\text { Candidate }\end{array}$ \\
\hline
\end{tabular}




\begin{tabular}{|c|c|c|c|c|c|}
\hline No. & $\begin{array}{c}\text { Stock } \\
\text { Code }\end{array}$ & $\mathrm{E}(\mathrm{Ri})$ & $\mathrm{E}(\mathrm{Rm})$ & $\begin{array}{c}\mathrm{E}(\mathrm{Rm})- \\
\mathrm{E}(\mathrm{Rm})\end{array}$ & $\begin{array}{c}\text { Portfolio } \\
\text { Former }\end{array}$ \\
\hline 21 & PGAS & $\begin{array}{c}- \\
0.0775\end{array}$ & 0.0242 & $\begin{array}{c}- \\
0.1017\end{array}$ & $\begin{array}{l}\text { Not } \\
\text { Candidate }\end{array}$ \\
\hline
\end{tabular}

From the table above, it can be seen that there are 14 stocks that have a positive value, which means they are included in the portfolio forming stocks. These shares are WSKT, BBCA, BBNI, ADRO, TLKM, UNVR, PWON, INDF, UNTR, ICBP, and GGRM. Meanwhile, the stocks that are not included in the portfolio forming stocks are INTP, ASII, JSMR, KLBF, WIKA, SMGR, BMRI, BBRI, PTBA, and

PGAS. To ensure that the fourteen shares have a positive value.

The results of measuring portfolio performance are: Sharpe Index, Treynor Index, and Jensen Index. This comparison aims to determine which portfolio calculations are more optimal than other portfolios.

1. Return of Portfolio E (Rp): $0.0717 \diamond 7.17 \%$

2. Standard Deviation $\sigma: 0.2120$

3. Beta $\beta: 0.4567$

4. Stock return Rf: 0.0614

5. Rm market return: 0.0552

6. Shape Ratio SR: 0.0485

7. Trenor Ratio TR: 0.0225

8. Jensen Ratio JR: 0.0131

The error variance resulted from the diversification of investment in the form of a portfolio of 11 stocks, where the more the number of shares included in the portfolio, the less systematic risk is expected to be.

\section{Single Index Model}

The closing price in each December in the 2015-2019 study period can be seen in the table. Next, calculate the Single Index Model as follows:

1. Actual return, expected stock return, and stock standard deviation Furthermore, based on the results of the calculation of actual return, the expected return and the standard deviation of shares ( $\sigma \mathrm{i})$ are calculated as follows:

Results Actual return, expected stock return, and stock standard deviation

\begin{tabular}{|c|l|c|c|}
\hline No. & Stock Code & $\mathrm{E}(\mathrm{Ri})$ & $\sigma_{\mathrm{i}}$ \\
\hline 1 & ADRO & 0.1721 & 0.1527 \\
\hline 2 & ASII & 0.0157 & 0.0234 \\
\hline 3 & BBCA & 0.1095 & 0.0039 \\
\hline 4 & BBNI & 0.0733 & 0.0337 \\
\hline 5 & BBRI & -0.0091 & 0.0856 \\
\hline 6 & BMRI & -0.0046 & 0.0314 \\
\hline 7 & GGRM & 0.0213 & 0.0257 \\
\hline 8 & ICBP & 0.0016 & 0.0208 \\
\hline 9 & INDF & 0.0502 & 0.0510 \\
\hline 10 & INTP & 0.0206 & 0.0497 \\
\hline 11 & JSMR & 0.0121 & 0.0508 \\
\hline 12 & KLBF & 0.0064 & 0.0287 \\
\hline 13 & PGAS & -0.0488 & 0.0325 \\
\hline 14 & PTBA & 0.0819 & 0.2929 \\
\hline 15 & PWON & 0.0636 & 0.0614 \\
\hline 16 & SMGR & 0.0380 & 0.0421 \\
\hline 17 & TLKM & 0.0454 & 0.0247 \\
\hline 18 & UNTR & 0.0287 & 0.0473 \\
\hline 19 & UNVR & 0.0172 & 0.0239 \\
\hline
\end{tabular}




\begin{tabular}{|c|l|c|c|}
\hline No. & Stock Code & $\mathrm{E}(\mathrm{Ri})$ & $\sigma_{\mathrm{i}}$ \\
\hline 20 & WIKA & -0.0140 & 0.0373 \\
\hline 21 & WSKT & 0.0090 & 0.0690 \\
\hline
\end{tabular}

Market return and expected market return and market standard deviation

Market return is calculated using the formula:

$$
R_{m}=\frac{L Q 45_{t}-L Q 45_{t-1}}{L Q 45_{t-1}}
$$

From the calculation results, the expected market return can be calculated using the following formula:

$\mathrm{E}(\mathrm{Rm})=0.0288$

The market standard deviation can be found using the formula:

$\sigma \mathrm{m}=0.0060$

1. Stock Beta, Stock Alpha, Residue, ERB, and RF

Before calculating the ERB, first calculating Rf, in this study, risk-free asset returns are represented by the daily SBI interest rate during the 2015-2019 period.

Obtained in the $2015-2019$ period $\mathrm{Rf}=0.0614$ or $6.14 \%$. Calculation results for Stock Beta, Stock Alpha, Residue, and ERB.

2. Cut off point $(\mathrm{C} *)$

Cut Off Point $(\mathrm{C} *)$ is a limiting point used to determine whether a stock can be included in the portfolio or not. Cut Off Point $\left(\mathrm{C}^{*}\right)$ is the largest value of the values of the limiting point $(\mathrm{Ci})$ of the stocks that are the candidate portfolio. Some steps to determine the cut off point value are:

a. Calculating the value of Ai by subtracting the expected return by Rf, the result of the subtraction is multiplied by beta and then divided by the variance of error.

b. Calculating Bi by squaring beta then the result divided by the variance of error.

c. Calculating the value of $\mathrm{Ci}$ by multiplying the market variance then multiplying by $\mathrm{Ai}$ divided by the sum + market variance times $\mathrm{Bi}$.

Determination of Cut Off Point $\left(\mathrm{C}^{*}\right)$

\begin{tabular}{|c|c|c|c|c|c|c|}
\hline $\begin{array}{c}\text { No } \\
\cdot\end{array}$ & Code & $\alpha_{\mathrm{i}}$ & $\beta_{\mathrm{i}}$ & $\sigma_{\mathrm{m}}{ }^{2}$ & $\mathrm{ERB}$ & $\mathrm{Ci}$ \\
\hline 1 & $\begin{array}{c}\mathrm{ADR} \\
\mathrm{O}\end{array}$ & $\begin{array}{c}0.134 \\
2\end{array}$ & $\begin{array}{c}1.314 \\
0\end{array}$ & $\begin{array}{c}0.16 \\
31\end{array}$ & $\begin{array}{c}0.12 \\
34\end{array}$ & $\begin{array}{c}0.007 \\
4\end{array}$ \\
\hline 2 & $\mathrm{ASII}$ & $\begin{array}{c}0.014 \\
9\end{array}$ & $\begin{array}{c}1.062 \\
5\end{array}$ & $\begin{array}{c}0.03 \\
01\end{array}$ & $\begin{array}{c}0.00 \\
54\end{array}$ & $\begin{array}{c}0.001 \\
0\end{array}$ \\
\hline 3 & $\begin{array}{c}\mathrm{BBC} \\
\mathrm{A}\end{array}$ & $\begin{array}{c}0.097 \\
2\end{array}$ & $\begin{array}{c}0.428 \\
0\end{array}$ & $\begin{array}{c}0.00 \\
51\end{array}$ & $\begin{array}{c}0.23 \\
26\end{array}$ & $\begin{array}{c}0.041 \\
7\end{array}$ \\
\hline 4 & $\begin{array}{c}\mathrm{BBN} \\
\mathrm{I}\end{array}$ & $\begin{array}{c}0.015 \\
1\end{array}$ & $\begin{array}{c}2.018 \\
7\end{array}$ & $\begin{array}{c}0.05 \\
82\end{array}$ & $\begin{array}{c}0.03 \\
14\end{array}$ & $\begin{array}{c}0.009 \\
3\end{array}$ \\
\hline 5 & $\begin{array}{c}\mathrm{BBR} \\
\mathrm{I}\end{array}$ & $\begin{array}{c}0.003 \\
-\end{array}$ & $\begin{array}{c}0.183 \\
2\end{array}$ & $\begin{array}{c}0.08 \\
58\end{array}$ & $\begin{array}{c}0.10 \\
41\end{array}$ & $\begin{array}{c}0.000 \\
2\end{array}$ \\
\hline 6 & $\begin{array}{c}\mathrm{BMR} \\
\mathrm{I}\end{array}$ & $\begin{array}{c}0.015 \\
4\end{array}$ & $\begin{array}{c}0.372 \\
6\end{array}$ & $\begin{array}{c}0.03 \\
22\end{array}$ & $\begin{array}{c}0.03 \\
91\end{array}$ & $\begin{array}{c}0.001 \\
0\end{array}$ \\
\hline 7 & $\begin{array}{c}\mathrm{GGR} \\
\mathrm{M}\end{array}$ & $\begin{array}{c}0.015 \\
1\end{array}$ & $\begin{array}{c}1.261 \\
6\end{array}$ & $\begin{array}{c}0.03 \\
53\end{array}$ & $\begin{array}{c}0.00 \\
90\end{array}$ & $\begin{array}{c}0.001 \\
9\end{array}$ \\
\hline 8 & $\begin{array}{c}\mathrm{ICBP} \\
0.018 \\
0\end{array}$ & $\begin{array}{c}0.566 \\
9\end{array}$ & $\begin{array}{c}0.02 \\
27\end{array}$ & $\begin{array}{c}0.01 \\
47\end{array}$ & $\begin{array}{c}0.001 \\
2\end{array}$ \\
\hline
\end{tabular}




\begin{tabular}{|c|c|c|c|c|c|c|}
\hline No & Code & $\alpha_{\mathrm{i}}$ & $\beta_{\mathrm{i}}$ & $\sigma_{\mathrm{m}}{ }^{2}$ & ERB & $\mathrm{Ci}$ \\
\hline 9 & $\begin{array}{c}\text { IND } \\
F\end{array}$ & $\begin{array}{c}0.000 \\
2 \\
\end{array}$ & $\begin{array}{c}1.748 \\
3\end{array}$ & $\begin{array}{c}0.06 \\
94\end{array}$ & $\begin{array}{c}0.02 \\
30\end{array}$ & $\begin{array}{c}0.004 \\
8\end{array}$ \\
\hline 10 & INTP & $\begin{array}{c}- \\
0.021 \\
0\end{array}$ & $\begin{array}{c}1.440 \\
9\end{array}$ & $\begin{array}{c}0.06 \\
22\end{array}$ & $\begin{array}{c}0.00 \\
74\end{array}$ & $\begin{array}{c}0.001 \\
2\end{array}$ \\
\hline 11 & $\begin{array}{c}\text { JSM } \\
\text { R }\end{array}$ & $\begin{array}{c}- \\
0.040 \\
5 \\
\end{array}$ & $\begin{array}{c}1.827 \\
0\end{array}$ & $\begin{array}{c}0.07 \\
09\end{array}$ & $\begin{array}{c}0.00 \\
12\end{array}$ & $\begin{array}{c}0.000 \\
3\end{array}$ \\
\hline 12 & $\begin{array}{c}\text { KLB } \\
\text { F }\end{array}$ & $\begin{array}{c}- \\
0.042 \\
1\end{array}$ & $\begin{array}{c}1.684 \\
0\end{array}$ & $\begin{array}{c}0.04 \\
57\end{array}$ & $\begin{array}{c}0.00 \\
21\end{array}$ & $\begin{array}{c}- \\
0.000 \\
6\end{array}$ \\
\hline 13 & $\begin{array}{c}\text { PGA } \\
\mathrm{S}\end{array}$ & $\begin{array}{c}- \\
0.060 \\
8 \\
\end{array}$ & $\begin{array}{c}0.415 \\
7\end{array}$ & $\begin{array}{c}0.03 \\
35\end{array}$ & $\begin{array}{c}- \\
0.14 \\
14\end{array}$ & $\begin{array}{c}- \\
0.004 \\
3 \\
\end{array}$ \\
\hline 14 & $\begin{array}{c}\text { PTB } \\
\text { A }\end{array}$ & $\begin{array}{c}0.103 \\
5\end{array}$ & $\begin{array}{c}- \\
0.750 \\
8\end{array}$ & $\begin{array}{c}0.29 \\
62\end{array}$ & $\begin{array}{c}- \\
0.09 \\
58 \\
\end{array}$ & $\begin{array}{c}- \\
0.001 \\
1\end{array}$ \\
\hline 15 & $\begin{array}{c}\text { PWO } \\
\mathrm{N}\end{array}$ & $\begin{array}{c}- \\
0.006 \\
9\end{array}$ & $\begin{array}{c}2.443 \\
7\end{array}$ & $\begin{array}{c}0.09 \\
73\end{array}$ & $\begin{array}{c}0.02 \\
19\end{array}$ & $\begin{array}{c}0.005 \\
9\end{array}$ \\
\hline 16 & $\begin{array}{c}\text { SMG } \\
\text { R }\end{array}$ & $\begin{array}{c}0.018 \\
4\end{array}$ & $\begin{array}{c}0.678 \\
0\end{array}$ & $\begin{array}{c}0.04 \\
49\end{array}$ & $\begin{array}{c}0.04 \\
13\end{array}$ & $\begin{array}{c}0.002 \\
4\end{array}$ \\
\hline 17 & $\begin{array}{c}\text { TLK } \\
\text { M }\end{array}$ & $\begin{array}{c}0.001 \\
7 \\
\end{array}$ & $\begin{array}{c}1.516 \\
6 \\
\end{array}$ & $\begin{array}{c}0.03 \\
86\end{array}$ & $\begin{array}{c}0.02 \\
34 \\
\end{array}$ & $\begin{array}{c}0.006 \\
2 \\
\end{array}$ \\
\hline 18 & $\begin{array}{c}\text { UNT } \\
\text { R }\end{array}$ & $\begin{array}{c}0.011 \\
8 \\
\end{array}$ & $\begin{array}{c}0.587 \\
5 \\
\end{array}$ & $\begin{array}{c}0.04 \\
94\end{array}$ & $\begin{array}{c}0.03 \\
20 \\
\end{array}$ & $\begin{array}{c}0.001 \\
3 \\
\end{array}$ \\
\hline 19 & $\begin{array}{c}\mathrm{UNV} \\
\mathrm{R}\end{array}$ & $\begin{array}{c}- \\
0.036 \\
2 \\
\end{array}$ & $\begin{array}{c}1.851 \\
1\end{array}$ & $\begin{array}{c}0.04 \\
45\end{array}$ & $\begin{array}{c}0.00 \\
39\end{array}$ & $\begin{array}{c}0.001 \\
2\end{array}$ \\
\hline 20 & $\begin{array}{c}\text { WIK } \\
\text { A }\end{array}$ & $\begin{array}{c}- \\
0.016 \\
6\end{array}$ & $\begin{array}{c}0.087 \\
6\end{array}$ & $\begin{array}{c}0.03 \\
73\end{array}$ & $\begin{array}{c}- \\
0.27 \\
38\end{array}$ & $\begin{array}{c}- \\
0.000 \\
3\end{array}$ \\
\hline 21 & $\begin{array}{c}\text { WSK } \\
\mathrm{T}\end{array}$ & $\begin{array}{c}- \\
0.030 \\
3\end{array}$ & $\begin{array}{c}1.362 \\
7\end{array}$ & $\begin{array}{c}0.08 \\
02\end{array}$ & $\begin{array}{c}- \\
0.00 \\
07\end{array}$ & $\begin{array}{c}- \\
0.000 \\
1\end{array}$ \\
\hline
\end{tabular}

d. Determine the value of $\mathrm{C} *$, which is the highest $\mathrm{Ci}$ value. The next step is to compare $\mathrm{C} *$ with ERB. Only stocks with ERB> $\mathrm{C} *$ are declared as stocks that make up the optimal portfolio. The results of the cut off point calculation and comparison of $\mathrm{C} *$ with ERB are presented in the following table:

Optimal Portfolio Determination

\begin{tabular}{|c|c|c|c|c|c|}
\hline $\begin{array}{c}\text { No } \\
.\end{array}$ & $\begin{array}{c}\text { Stock } \\
\text { Code }\end{array}$ & ERB & Ci & C $^{*}$ & $\begin{array}{l}\text { Informati } \\
\text { on }\end{array}$ \\
\hline 1 & $\begin{array}{c}\text { BBC } \\
\text { A }\end{array}$ & 0.2326 & 0.0417 & 0.0417 & Optimal \\
\hline 2 & $\begin{array}{c}\text { AD } \\
\text { RO }\end{array}$ & 0.1234 & 0.0074 & 0.0417 & Optimal \\
\hline 3 & $\begin{array}{c}\text { BBR } \\
\text { I }\end{array}$ & 0.1041 & 0.0002 & 0.0417 & Optimal \\
\hline
\end{tabular}




\begin{tabular}{|c|c|c|c|c|c|}
\hline No & $\begin{array}{l}\text { Stock } \\
\text { Code }\end{array}$ & ERB & $\mathrm{Ci}$ & $\mathrm{C}^{*}$ & $\begin{array}{l}\text { Informati } \\
\text { on }\end{array}$ \\
\hline 4 & $\begin{array}{l}\text { SM } \\
\text { GR }\end{array}$ & 0.0413 & 0.0024 & 0.0417 & - \\
\hline 5 & $\begin{array}{c}\text { UNT } \\
\text { R }\end{array}$ & 0.0320 & 0.0013 & 0.0417 & - \\
\hline 6 & $\begin{array}{c}\text { BBN } \\
\text { I }\end{array}$ & 0.0314 & 0.0093 & 0.0417 & - \\
\hline 7 & $\begin{array}{c}\text { TLK } \\
\text { M }\end{array}$ & 0.0234 & 0.0062 & 0.0417 & - \\
\hline 8 & $\begin{array}{c}\text { IND } \\
F\end{array}$ & 0.0230 & 0.0048 & 0.0417 & - \\
\hline 9 & $\begin{array}{l}\text { PW } \\
\text { ON }\end{array}$ & 0.0219 & 0.0059 & 0.0417 & - \\
\hline 10 & $\begin{array}{c}\text { ICB } \\
\text { P }\end{array}$ & 0.0147 & 0.0012 & 0.0417 & - \\
\hline 11 & $\begin{array}{l}\text { GG } \\
\text { RM }\end{array}$ & 0.0090 & 0.0019 & 0.0417 & - \\
\hline 12 & $\begin{array}{c}\text { INT } \\
\mathrm{P}\end{array}$ & 0.0074 & 0.0012 & 0.0417 & - \\
\hline 13 & ASII & 0.0054 & 0.0010 & 0.0417 & - \\
\hline 14 & $\begin{array}{l}\text { UN } \\
\text { VR }\end{array}$ & 0.0039 & 0.0012 & 0.0417 & - \\
\hline 15 & $\begin{array}{c}\text { JSM } \\
\text { R }\end{array}$ & 0.0012 & 0.0003 & 0.0417 & - \\
\hline 16 & $\begin{array}{l}\text { WS } \\
\text { KT }\end{array}$ & $\begin{array}{c}- \\
0.0007 \\
\end{array}$ & $\begin{array}{c}- \\
0.0001 \\
\end{array}$ & 0.0417 & - \\
\hline 17 & $\begin{array}{c}\text { KLB } \\
\text { F }\end{array}$ & $\begin{array}{c}- \\
0.0021 \\
\end{array}$ & $\begin{array}{c}- \\
0.0006 \\
\end{array}$ & 0.0417 & - \\
\hline 18 & $\begin{array}{c}\mathrm{BM} \\
\mathrm{RI}\end{array}$ & $\begin{array}{c}- \\
0.0391 \\
\end{array}$ & $\begin{array}{c}- \\
0.0010 \\
\end{array}$ & 0.0417 & - \\
\hline 19 & $\begin{array}{c}\text { PTB } \\
\text { A }\end{array}$ & $\begin{array}{c}- \\
0.0958 \\
\end{array}$ & $\begin{array}{c}- \\
0.0011 \\
\end{array}$ & 0.0417 & - \\
\hline 20 & $\begin{array}{c}\text { PGA } \\
\text { S }\end{array}$ & $\begin{array}{c}- \\
0.1414 \\
\end{array}$ & $\begin{array}{c}- \\
0.0043 \\
\end{array}$ & 0.0417 & - \\
\hline 21 & $\begin{array}{c}\text { WIK } \\
\text { A }\end{array}$ & $\begin{array}{c}- \\
0.2738 \\
\end{array}$ & $\begin{array}{c}- \\
0.0003 \\
\end{array}$ & 0.0417 & - \\
\hline
\end{tabular}

1. Proportion of shares i

The proportion of shares $\mathrm{i}(\mathrm{Wi})$ is the proportion of funds for each share in the portfolio as follows:

Determination of the Proportion of Shares i (Wi)

Determination of the Proportion of Shares in the Optimal Portfolio

\begin{tabular}{|c|c|c|c|c|}
\hline No. & Stock & $\mathrm{Zi}$ & Wi & $\begin{array}{c}\text { Stock } \\
\text { Proportion }\end{array}$ \\
\hline 1 & BBCA & $\begin{array}{c}16.1779 \\
8\end{array}$ & $\begin{array}{c}0.95335 \\
4\end{array}$ & $95.34 \%$ \\
\hline 2 & ADRO & $\begin{array}{c}0.65825 \\
6\end{array}$ & 0.03879 & $3.88 \%$ \\
\hline 3 & BBRI & 0.1333 & $\begin{array}{c}0.00785 \\
5\end{array}$ & $0.79 \%$ \\
\hline
\end{tabular}




\begin{tabular}{|l|c|c|c|c|}
\hline & $\begin{array}{c}\text { Jumla } \\
\mathrm{h}\end{array}$ & $\begin{array}{c}16.9695 \\
4\end{array}$ & 1.0000 & $100 \%$ \\
\hline
\end{tabular}

The results of measuring portfolio performance are: Sharpe Index, Treynor Index, and Jensen Index. This comparison aims to determine which portfolio calculations are more optimal than other portfolios.

1. Return Portfolio E (Rp): $0.1110=11.10 \%$

2. Standard Deviation $\sigma: 0.0677$

3. Beta $\beta: 0.4575$

4. Stock return Rf: 0.0591

5.Rm market return: 0.0288

6. Shape Ratio SR: 0.7658

7. Trenor Ratio TR: 0.1134

8. Jensen Ratio JR: 0.0657

The return variance resulted from the diversification of investment in the form of a Single Index Model portfolio of 3 stocks.

\section{Portfolio Comparison Analysis}

To explain the statistical differences in the resulting portfolios, it is necessary to test the hypothesis. Hypothesis testing is performed using the Paired t-test to compare the mean of two paired samples. In the Paired t-test, the value of $\alpha=0.05$ or $5 \%$ was used. Paired t-test.

\section{Comparison of Portfolio Formation with Random Model and Markowitz Method}

The random model uses four trials where the selected result is a random process that produces the largest portfolio return with an expected return of 0.4270 or $42.70 \%$ with an average of 0.0488 or $4.88 \%$ and the Markowitz method with an expected return of 0.0717 or $7.17 \%$.

The results of the paired t-test used Ho test: the mean portfolio return with the Random Model is no difference with the return Markowitz method produces sig. $=0.03$. Because the $p$ value is smaller than the $\alpha$ value of 0.05 , maha Ho is accepted, this indicates that there is a significant difference between the formation of a random model portfolio with the Markowitz method.

In terms of forming a portfolio, the Markowitz model has a variance of return (risk) of 0.0614 or $6.14 \%$. These results indicate that the percentage is greater than the Random method, namely 0.0102 or $1.02 \%$.

\section{Comparison of Portfolio Formation with Random Model and Single Index Model method}

The calculation results show that the portfolio with the Single Index Model method can reduce the beta (risk) of stocks for stock diversification using the SIM method can reduce risk. From the method there are 14 stocks that have a positive value, which means they are included in the portfolio forming stocks.

The results of the paired t-test used to test Ho: mean portfolio returns with the Random Model is no difference with the return of the Single Index Model method produces sig. $=0.345$. Because the $p$ value is greater than the $\alpha$ value of 0.05 , maha Ho is rejected, this indicates that there is a significant difference between the formation of a random model portfolio with the Single Index Model method.

For the formation of a portfolio, the Single Index Model method has a return (risk) variant of 0.0591 or $5.91 \%$, this percentage is greater than the Random method, which is 0.0102 or $1.02 \%$.

3. Comparison of Portfolio Formation with the Markowitz method and the Single Index Model method

The calculation results show that the portfolio with the Markowitz method is superior to that of the Single Index Model portfolio. This is in accordance with the portfolio with the Markowitz method which has better results than the portfolio with the Single Index Model method. 
The results of the paired t-test used to test Ho: the mean portfolio return with the Markowitz method is that there is a difference with the return of the Single Index Model method which produces sig. $=0.003$. Because the $\mathrm{p}$ value is smaller than the $\alpha$ value of 0.05 , maha Ho is accepted, this indicates that there is a significant difference between the formation of a portfolio using the Markowitz method and the Single Index Model method.

For the formation of a portfolio, the Markowitz method has a return (risk) variant of 0.0717 or $7.17 \%$, this percentage is greater than the Single Index Model method, which is 0.0591 or $5.91 \%$.

\section{Portfolio Risk Analysis}

The portfolio risk analysis used in this research is Value at Risk (VaR) which is a measure of the risk of loss for investment. It estimates how much an investment might lose (with a given probability), given normal market conditions, in a given period of time.

The formation of a portfolio used for analysis in this study, the calculation steps are as follows:

\section{Portfolio formation}

In forming the portfolio used is the result of the Markowitz method with 14 stocks listed on the LQ 45 Index during the 2015-2019 period. The number of shares used for this calculation is between 100-500 shares with prices in the last week of December 2019. The results of the formation are as follows:

Formation of Shares in the Markowitz Method Portfolio

\begin{tabular}{|l|c|c|c|c|}
\hline \multirow{2}{*}{$\begin{array}{l}\text { Stock } \\
\text { Code }\end{array}$} & \multirow{2}{*}{ Amount } & Price & Volume & Share \\
\cline { 3 - 5 } & & $\mathrm{Rp}$ & $\mathrm{Rp}$ & $\%$ \\
\hline ADRO & 100 & 1555 & 155,500 & $1.79 \%$ \\
\hline ASII & 200 & 6,925 & $1,385,000$ & $3.57 \%$ \\
\hline BBCA & 200 & 33,425 & $6,685,000$ & $3.57 \%$ \\
\hline BBNI & 200 & 7,850 & $1,570,000$ & $3.57 \%$ \\
\hline GGRM & 400 & 53,000 & $21,200,000$ & $7.14 \%$ \\
\hline ICBP & 500 & 11,150 & $5,575,000$ & $8.93 \%$ \\
\hline INDF & 500 & 7,925 & $3,962,500$ & $8.93 \%$ \\
\hline INTP & 500 & 19,025 & $9,512,500$ & $8.93 \%$ \\
\hline PTBA & 500 & 2,650 & $1,325,000$ & $8.93 \%$ \\
\hline PWON & 500 & 570 & 285,000 & $8.93 \%$ \\
\hline TLKM & 500 & 3,970 & $1,985,000$ & $8.93 \%$ \\
\hline UNTR & 500 & 21,575 & $10,787,500$ & $8.93 \%$ \\
\hline UNVR & 500 & 42,000 & $21,000,000$ & $8.93 \%$ \\
\hline WSKT & 500 & 1,485 & 742,500 & $8.93 \%$ \\
\hline Jumlah & 5.600 & & $86,170,500$ & $100.0 \%$ \\
\hline
\end{tabular}

Next determine the performance according to the price of each share in the 24 month period from January 2018 to December 2019.

1) Determination of the Confidence Interval

The confidence interval used in the risk analysis of stock formation is $95 \%$ or 0.95 .

2) Calculation of the $K$ coefficient

The $\mathrm{K}$ coefficient is the inverse value of the standard normal distribution in a calculation using the Microsoft Excel program using the NORMSINV function to calculate this: Kcoefficient $=1.64485$

3) Calculation of Average Change Each Month and Standard Deviation

The results of calculating the average change every month and Standard Deviation in the formation of portfolios for the Markowitz method are as follows:

Average Employment and Standard Deviation of Portfolio Formation 


\begin{tabular}{|l|c|c|}
\hline Stock Code & $\begin{array}{c}\text { Average Monthly } \\
\text { Change }\end{array}$ & $\begin{array}{c}\text { Standart } \\
\text { Deviation }\end{array}$ \\
\hline ADRO & -0.01193 & 0.236402 \\
\hline ASII & 0.00017 & 0.057957 \\
\hline BBCA & 0.007468 & 0.057801 \\
\hline BBNI & 0.000982 & 0.088683 \\
\hline GGRM & 0.003246 & 0.064011 \\
\hline ICBP & 0.009557 & 0.058178 \\
\hline INDF & 0.000129 & 0.06314 \\
\hline INTP & 0.00366 & 0.146819 \\
\hline PTBA & 0.015065 & 0.099829 \\
\hline PWON & -0.00229 & 0.090597 \\
\hline TLKM & -0.00105 & 0.058183 \\
\hline UNTR & -0.00856 & 0.123744 \\
\hline UNVR & -0.00565 & 0.068955 \\
\hline WSKT & -0.00929 & 0.182873 \\
\hline
\end{tabular}

\section{Calculation of Monthly Volatility Multiplier}

The calculation steps are: 1) creating a link to the number of shares, 2) creating a link to the share price, 3) calculating the position value by means of the price multiplied by the number, 4) creating a link to the monthly volatility, 5) calculating the volatility multiplier by means of the monthly volatility times the position value, 6) Create a link to the average monthly change, and 7) calculate the average monthly change in rupiah, by calculating the average monthly change times the position value.

2. Calculation of the Volatility Multiplier

Next Steps to calculate the volatility multiplier for 12 months by: the result of the multiplier of monthly volatility multiplied by the square root of 12 and calculate the average price change for 12 months by: calculating the average monthly change multiplied by during the period, namely 12.

3. Calculating the Correlation between Shares

At this stage, a matrix is made to calculate the correlation between all stocks and calculation of the correlation using the CORREL function in the Microsoft Excel program.

4. Calculate VaR for 1 month and 12 months

Before calculating the VaR for 1 month and 12 months, first make two columns with the volatility multiplier of 1 month and 12 months by loading links to the monthly and 12 month volatility multipliers, from these calculations calculated portfolio volatility and calculating the square root of the results and for matrix multiplication. use the MMULT function in the Microsoft Excel program. It then makes a similar calculation for a 12 month period, calculating the average change for the portfolio and for the monthly average of all stocks as well as the 12 month change from the calculated price. From the calculation, the result shows that the risk of loss in the formation of a portfolio which is converted into LQ45 shares is Rp. -7,186,626 ($8.34 \%$ ) for monthly investment periods or Rp. $-20,011,109$ (-23.22\%). The amount of the simulated investment is $\mathrm{Rp} .86,170,500$ with 14 stocks in portfolio formation.

The Composite Stock Price Index (IHSG) is an index that measures the price of shares sold on the stock exchange. IHSG is an important indicator for a country's economy. The ups and downs of the JCI indicate the ups and downs of investment interest, especially those carried out through the stock exchange floor. In investing there are risks that must be taken into account so as not to make decisions in choosing a portfolio. Therefore, an instrument is needed to measure market risk, in order to know the extent to which investors can invest safely. Several 
instruments that can be used to estimate market risk include Value at Risk (VaR). VaR also describes the estimated probability of a loss that can be suffered in an amount greater than the predetermined amount of loss. This condition allows the measurement of the reduced risk caused by portfolio diversification efforts.

\section{CONCLUSION}

There are several methods of determining optimal portfolios that can be used by investors, including the random model portfolio, the Markowitz method, and the Single Index Model (SIM) method. From the calculation results, the random model portfolio formation results in a combination of ADRO, BBCA, BMRI, ICBP, INDF stocks. JSMR, PWON, SMGR, UNTR, and UNVR. Based on the results of the calculations carried out, the portfolio using the Single Index Model method produces a portfolio composition of stocks with an expected return that is greater than the results of the calculation, indicating that a portfolio using SIM can reduce the risk of each constituent issuer that investors are likely to bear in the future. , Portfolios using the Markowitz method produce a portfolio composition of stocks, ADRO, ASII, BBCA, BBNI, GGRM, ICBP, INDF, INTP, PTBA, PWON, TLKM, UNTR, UNVR, and WSKT. 4.95\%. Based on the analysis of the performance of the Risk Adjusted Return tested by calculating the Sharpe Index, Treynor Index and Jensen Index, it can be concluded that the performance of the Markowitz method portfolio is better than the performance of the Single Index Model Portfolio.

By using the Markowitz method from the results of the portfolio formation, it can be concluded that the risk of portfolio formation is $\mathrm{VaR}=-8.34 \%$ for the monthly period and $-23.22 \%$ for the 12 month period.

\section{REFERENCES}

Fahmi, Irham and Hadi, Yovi Lavianti (2012). Portfolio Theory and Investment Analysis, Bandung: Alfabeta,

Hartono, Jogiyanto (2016). Portfolio Theory and Investment Analysis: Tenth Edition, Yogyakarta: BPFE-Yogyakarta.

Husnan, Suad (2009). Basics of Portfolio Theory and Securities Analysis, 4th Edition, UPP STIM YKPN, Yogyakarta

Jones, Charles P (2007). Investments Analysis and Management, Tenth dition, John Wiley \& Sons, Inc, John Wiley \& Sons.

Mary, J, Francis and G, Rathika (2015). The Single Index Model and The Construction of Optimal Portfolio with Scrip, International Journal of Management, Vol, 6 No, 1

Sari, N., \& Triyani, Y. (2018). Pengaruh Audit Tenure, Debt Default, Kualitas Audit Dan Opini Audit Terhadap Opini Audit Going Concern Pada Perusahaan Manufaktur Yang Terdaftar Di Bursa Efek Indonesia. Akuntansi, 71. http://jurnal.kwikkiangie.ac.id/index.php/JA/issue/view/58

Yuliani, F., \& Achsani, N. A. (2017). Analisis Pembentukan Portofolio Berbasis Risk dan Return (Studi Kasus Saham di Jakarta Islamic Index Periode Juni 2011 - Mei 2016 ) Analysis of Portfolio Establishment Based on Risk and Return ( Case Study of Stocks in Jakarta Islamic Index June 2011 - M. Jurnal Al-Muzara'ah, 5(2), 134-145. ttps://doi.org/10.29244/jam.5.2.134145

Abdul Muslim (Return and Risk Comparative Analysis in the Formation of Optimal ...) 